\title{
Legislative Conditions for Intermodal Transport in Slovakia
}

\author{
Juraj Jagelčák ${ }^{1, *}$, Monika Kiktová ${ }^{\text {, }}$ and Jaroslava Kubáňová ${ }^{1}$ \\ ${ }^{1}$ University of Žilina, Faculty of Operation and Economics of Transport and Communications \\ Department of Road and Urban transport, Univerzitná 1, 01026 Žilina, Slovak Republic
}

\begin{abstract}
This article deals with conditions for intermodal transport in Slovakia. The first part of the article describes definition "combined transport" and "intermodal transport". Maximum allowed lengths, axle loads and masses of vehicles and vehicle combinations effective in Slovakia are given in summary figures. In the second part of the paper is described abnormal transport up to 60 tonnes in relation to a combined transport.
\end{abstract}

\section{Introduction}

In Slovakia, a term "combined transport" is defined in the Law no.514/2009 Z. z. on a railway transport where $\$ 2$ section 4 defines the combined transport using the definition from the Council Directive 92/106/EHS (identical text is not applied in Slovak definition): "Combined transport means the transport of goods between Member States where the lorry, trailer, semi-trailer, with or without tractor unit, swap body or transport container of 20 feet or more uses the road on the initial or final leg of the journey and, on the other leg, rail or inland waterway or maritime services where this section exceeds $100 \mathrm{~km}$ as the crow flies and make the initial or final road transport leg of the journey; - between the point where the goods are loaded and the nearest suitable rail loading station terminal of loading for the initial leg, and between the nearest suitable rail unloading station terminal of unloading and the point where the goods are unloaded for the final leg, or; - within a radius not exceeding $150 \mathrm{~km}$ as the crow flies from the inland waterway port or seaport of loading or unloading" [1].

The Council Directive 2015/719/ES states, that the limit of $150 \mathrm{~km}$ may be exceeded with intention to reach the nearest terminal suitable to provide intended service; the nearest suitable terminal may be placed in other Member State. The ,intermodal transport operation" is defined in the Government Regulation no. 349/2009 Z. z. on a maximum permissible dimensions and mass of vehicles and combinations (in relation with exceptions for these transports) as follows:

The intermodal transport operation is:

- $\quad$ the combined transport operation (As defined in Law no.514/2009 Z. z. on a railway transport); the nearest suitable transport terminal for the envisaged service may be placed in

* Corresponding author: juraj.jagelcak@,fpedas.uniza.sk 
other Member state than the Member State in which the shipment was loaded or unloaded, or

- transport operations engaged in the transport of one or more containers or swap bodies, up to a total maximum length of $45 \mathrm{feet} / 13.716 \mathrm{~m}$, using waterborne transport, provided that the length of the initial or the final road leg does not exceed $150 \mathrm{~km}$ in the territory of the Union; the distance of $150 \mathrm{~km}$ referred to above may be exceeded in order to reach the nearest suitable transport terminal for the envisaged service by the defined vehicles ; the nearest suitable transport terminal providing a service may be located in a Member State other than the Member State in which the shipment was loaded or unloaded. The Government Regulation no. 349/2009 Z. z. defines also the term „Loader“, similarly as it is defined in the ADR Convention. The Government Directive defines Loader as a person which loads goods into or onto a vehicle or into an intermodal loading unit or loads an intermodal loading unit onto a vehicle or vehicle combination.

Intermodal loading unit is defined as a container, swap body, semi-trailer or other similar loading unit suitable for use within intermodal transport.

\section{Driving restrictions in road freight transport in Slovakia}

The Law no. 8/2009 Z. z. on road traffic regulations sets restrictions of operation of some types of vehicles in $\S 39$. Operation of motor vehicles and combinations of maximum allowed mass exceeding $7500 \mathrm{~kg}$ and motor vehicles of maximum allowed mass exceeding $3500 \mathrm{~kg}$ articulated with a trailer on highways, motorways and 1st class roads is forbidden on the first rest day and on Saturday following after working day from 1st July to $31 \mathrm{st}$ August from 07:00 to 19:00 and on Sunday and the last rest day from 00:00 to 22:00. If only one rest day follows after a working day, the restriction is effective from 00:00 to 22:00. These restrictions are totally effective during about 75 days a year [1-4]

The vehicles used within a combined transport, for loading and discharge of ships, railway wagons or aircraft are not subject to these restrictions. However, also vehicles carrying dangerous goods (according to the ADR Convention) are not subject to these restrictions in general as well as carriages related to the use of such vehicles.

In addition to this, driving a freight vehicles or vehicle combinations with a maximum total allowed mass over $12000 \mathrm{~kg}$ is forbidden on the $3 \mathrm{rd}$ class roads, with the exception to serve specific area (mainly for vehicles being loaded or unloaded in a place accessible only by using such roads). Similar local restrictions are also on selected 2nd class roads (parallel with the toll roads). No specific exception from these restrictions applies to vehicles used within intermodal transports.

\section{Maximum allowed vehicle dimensions and masses in road and intermodal transport}

Maximum allowed vehicle dimensions and masses in Slovakia are based on the European Council Directives (96/53/ES, revised by 2015/719/EU), but some specific differences applies, some of them are applicable and important for intermodal transport.

A tandem axle means two axles in a row, the distance between the midpoints of which is not more than $1.8 \mathrm{~m}$ (partial wheelbase). A tridem axle means three axles in a row, the sum of partial wheelbases of which is not more than $2.8 \mathrm{~m}$. A load on an individual axle of a tandem or tridem axle of semi-trailers and trailers must not exceed $10 \mathrm{t}$.

Maximum allowed lengths, axle loads and masses of vehicles and vehicle combinations effective in Slovakia are given in following figures ( $\mathrm{CT}=$ combined transport). 

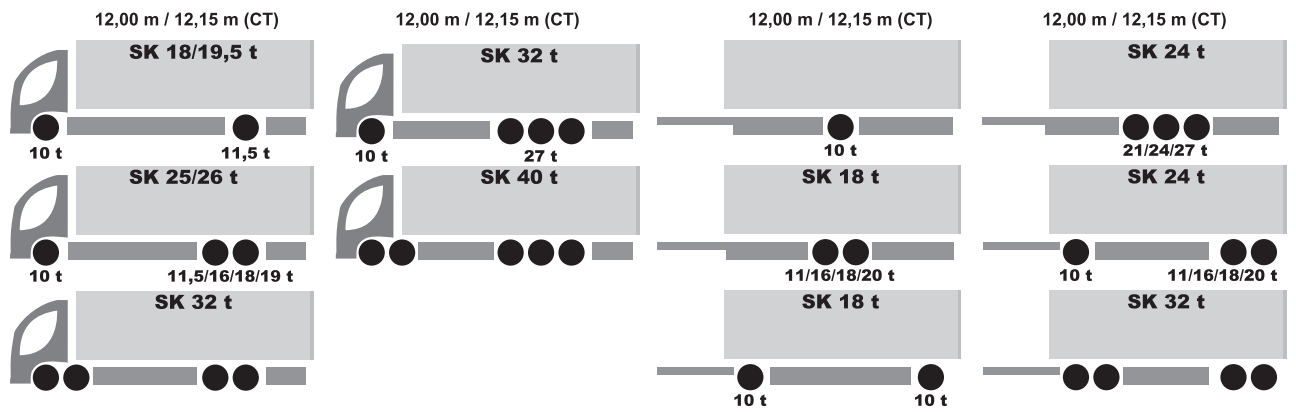

Fig. 1. Maximum parameters of typical vehicles and trailers. Source: [5]
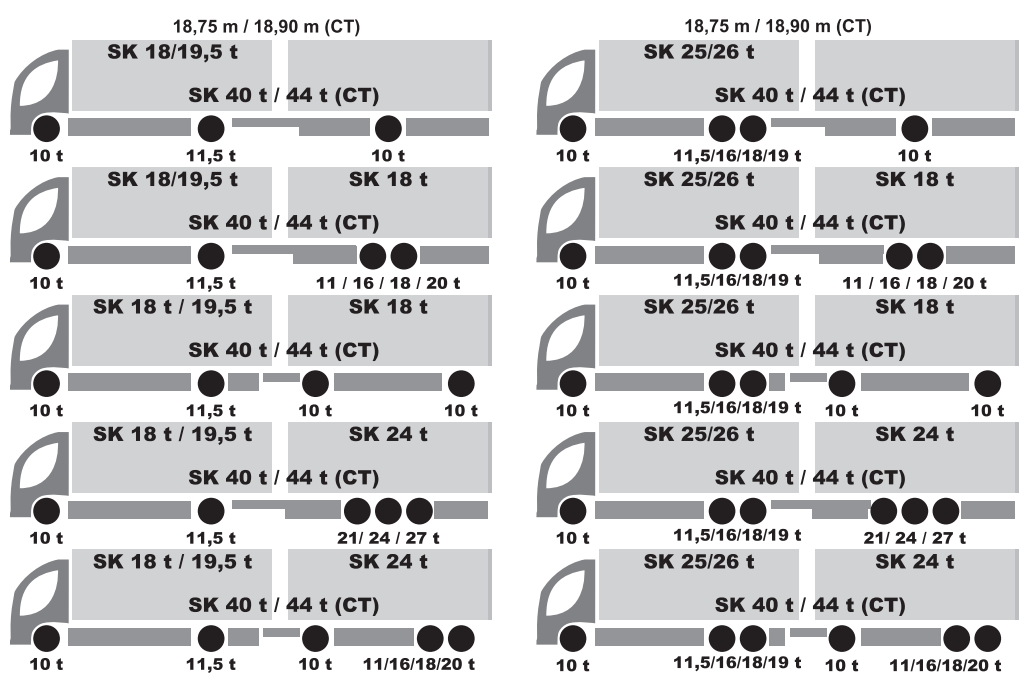

Fig. 2. Maximum parameters of typical road trains. Source: [5]
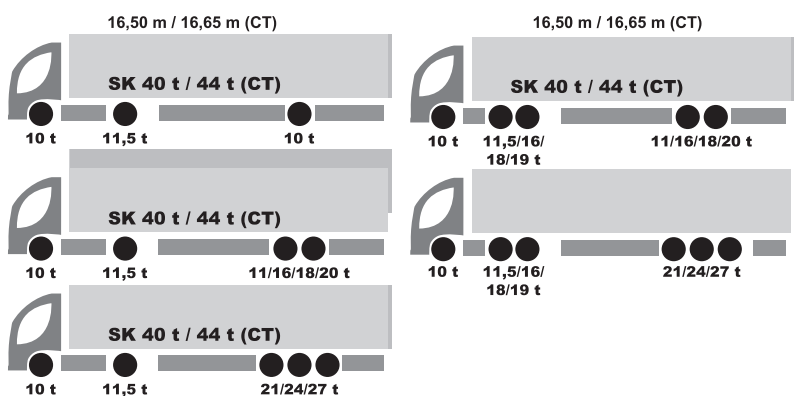

Fig. 3. Maximum parameters of typical semi-trailer combinations. Source: [5]

Following figure shows vehicle combinations consisting of a motor vehicle with two semi-trailers or with two trailers or with a semi-trailer and a trailer allowed in Slovakia (examples given, because legislation does not specify number of axles only the length and gross combination mass). 


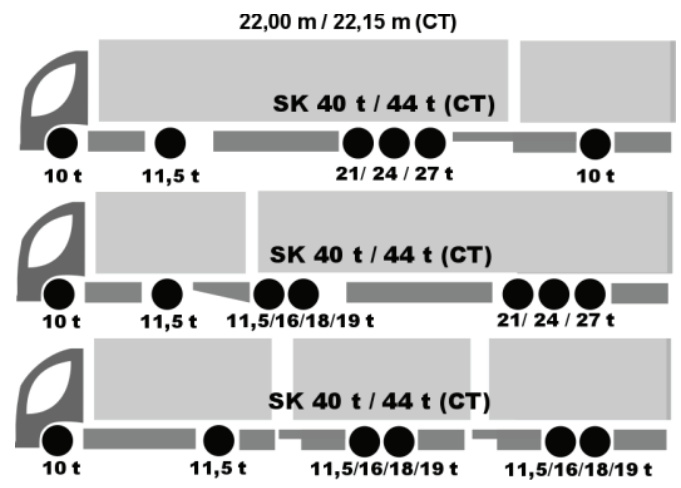

Fig. 4. Maximum parameters of vehicle combinations longer than $18.75 \mathrm{~m}$. Source: [5]

The following figure present semi-trailer combinations (2-axle tractor with 3-axle semitrailer or 3-axle tractor with 3-axle semi-trailer) typically used for intermodal transport of containers, tank containers, swap bodies and cranable semi-trailers. Vehicle combination $2+3$ is mostly used.

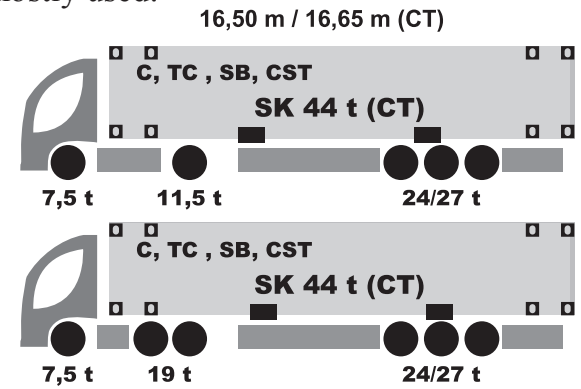

$$
\begin{aligned}
& \text { Key: } \\
& \mathrm{C}=\text { container } \\
& \mathrm{TC}=\text { tank container } \\
& \mathrm{SB}=\text { swap body } \\
& \mathrm{CST}=\text { cranable semi-trailer } \\
& \mathrm{CT}=\text { combined transport }
\end{aligned}
$$

Fig. 5. Typical semi-trailer combinations used for transport of various intermodal loading units. Source: [5]

The distance measured horizontally between the axis of the fifth-wheel king pin and any point at the front of the semi-trailer must not exceed $2.04 \mathrm{~m}$. Maximum distance between the axis of the fifth-wheel king pin and the rear of a semi-trailer is $12.00 \mathrm{~m} / 12.15 \mathrm{~m}$ (CT).

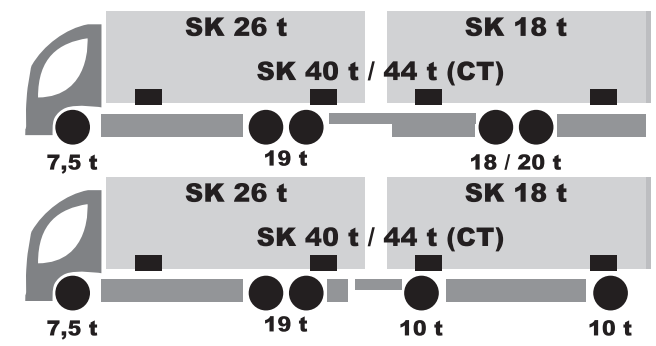

Fig. 6 Typical road trains used for a transport of C-swap bodies 22'-24' and 20' containers. Source: [5]

For road train the following condition (based on the requirement in the Directive 96/53/ES) has to be met: Maximum distance measured parallel to the longitudinal axis of the road train from the foremost external point of the loading area behind the cabin to the rearmost external point of the trailer of the combination, minus the distance between the rear of the drawing vehicle and the front of the trailer is $15.65 \mathrm{~m}$. It corresponds with length of two swap bodies C782 carried on a road train. 
Maximum distance measured parallel to the longitudinal axis of the road train from the foremost external point of the loading area behind the cabin to the rearmost external point of the trailer of the combination is $16.40 \mathrm{~m}$. The distance between the rear axle of a motor vehicle and the front axle of a trailer must not be less than $3.00 \mathrm{~m}$.

This requirement is not applicable for road trains with two trailers or with both a semitrailer and a trailer.

\subsection{Comparison of selected specific parameters of maximum allowed dimensions and mass of vehicles and vehicle combinations relevant for combined transport}

Table 1. Values valid in SLOVAKIA in comparison to EU directive are presented in following table. Source: [5]

\begin{tabular}{|c|c|c|}
\hline Parameter & Maximum limit Slovakia & $\begin{array}{l}\text { Maximum limit EU } \\
(2015 / 719 / \mathbf{E U})\end{array}$ \\
\hline $\begin{array}{l}\text { Max. allowed length of a semi-trailer } \\
\text { combination }\end{array}$ & $16.50 \mathrm{~m}^{1}$ & $16.50 \mathrm{~m}$ \\
\hline Max. allowed length of a road train & $18.75 \mathrm{~m}$ & $18.75 \mathrm{~m}^{2}$ \\
\hline $\begin{array}{l}\text { Max. allowed length of a combination } \\
\text { consisting of a motor vehicle with two } \\
\text { semi-trailers or with two trailers or } \\
\text { with a semi-trailer and a trailer }\end{array}$ & $22.00 \mathrm{~m}$ & $\begin{array}{l}16.50 \mathrm{~m} \text { or } 18.75 \mathrm{~m} \text { (such } \\
\text { category is not specifically } \\
\text { defined) }\end{array}$ \\
\hline $\begin{array}{l}\text { Max. allowed gross mass of a semi- } \\
\text { trailer combination used in } \\
\text { a combined transport }- \text { two-axle } \\
\text { tractor }+ \text { three-axle semi-trailer }\end{array}$ & $44 \mathrm{t}$ & $\begin{array}{l}42 \mathrm{t} \text { for transport of } \\
\text { containers/swap bodies; } \\
40 \mathrm{t} \text { for transport of cranable } \\
\text { semi-trailers }\end{array}$ \\
\hline $\begin{array}{l}\text { Max. allowed gross mass of a semi- } \\
\text { trailer combination used in } \\
\text { a combined transport }- \text { three-axle } \\
\text { tractor }+ \text { three-axle semi-trailer }\end{array}$ & $44 \mathrm{t}$ & $\begin{array}{l}44 \mathrm{t} \text { for transport of } \\
\text { containers/swap bodies; } \\
40 \mathrm{t} \text { for transport of cranable } \\
\text { semi-trailers }\end{array}$ \\
\hline $\begin{array}{l}\text { Max. allowed gross mass of a road } \\
\text { train used in a combined transport }\end{array}$ & $44 \mathrm{t}^{3}$ & $40 \mathrm{t}$ \\
\hline $\begin{array}{l}\text { Max. allowed gross mass of a vehicle } \\
\text { combination used otherwise than in a } \\
\text { combined transport }\end{array}$ & $40 \mathrm{t}$ & $40 \mathrm{t}$ \\
\hline $\begin{array}{l}\text { Max. allowed gross mass of a road } \\
\text { train with four axles consisting } \\
\text { of a two-axle motor vehicle and a two- } \\
\text { axle trailer }\end{array}$ & $\begin{array}{l}40 \mathrm{t} \\
\text { not specifically defined } \\
\text { but regarding particular } \\
\text { vehicle masses only } \\
18+18=36 \mathrm{t} \\
19.5+18=37.5 \mathrm{t}\end{array}$ & $36 \mathrm{t}$ \\
\hline Max. allowed mass of a semi-trailer & $40 \mathrm{t}$ & $36 \mathrm{t}$ \\
\hline
\end{tabular}

1,3 These lengths may be exceeded by $15 \mathrm{~cm}$ for vehicles/vehicle combinations operating in a combined transport in general.

${ }^{2,4}$ These lengths may be exceeded by $15 \mathrm{~cm}$ for vehicles/vehicle combinations engaged in the transport of 45-foot containers or 45-foot swap bodies, empty or loaded, provided that the road transport of the container or swap body in question is part of an intermodal transport operation in vehicles or vehicle combinations.

${ }^{3}$ If it is allowable for such type of combination regarding a maximum allowable axle load/mass of particular vehicles articulated in a combination; e.g. a combination of a two-axle motor vehicle and a three-axle trailer, has the maximum allowable gross mass of $42 / 43.5 \mathrm{t}$ due to max. gross masses of particular vehicles $(18 t+24 t$ or $19.5 t+24 t)$. 


\begin{tabular}{|c|c|c|}
\hline Parameter & Maximum limit Slovakia & $\begin{array}{l}\text { Maximum limit EU } \\
(2015 / 719 / \text { EU) }\end{array}$ \\
\hline $\begin{array}{l}\text { combination with four axles } \\
\text { consisting of a two-axle motor } \\
\text { vehicle and a two-axle semi-trailer, if } \\
\text { the distance between the axles of the } \\
\text { tandem axle of semi-trailer is } 1.3 \mathrm{~m} \leq \\
\mathrm{d} \leq 1.8 \mathrm{~m}\end{array}$ & $\begin{array}{l}\text { but regarding particular } \\
\text { axle loads as a theoretical } \\
\text { maximum } \\
10+11.5+18=39.5 \mathrm{t}\end{array}$ & \\
\hline $\begin{array}{l}\text { Max. allowed mass of a semi-trailer } \\
\text { combination with four axles } \\
\text { consisting of a two-axle motor } \\
\text { vehicle and a two-axle semi-trailer, if } \\
\text { the distance between the axles of the } \\
\text { semi-trailer is greater than } 1.8 \mathrm{~m}\end{array}$ & $\begin{array}{l}40 \mathrm{t} / \\
\text { but in combined transport } \\
\text { may be reached } \\
\text { as a theoretical maximum } \\
\text { regarding particular axle } \\
\text { loads } \\
10+11.5+20=41.5 \mathrm{t}\end{array}$ & $\begin{array}{l}38 \mathrm{t} \text { when the maximum } \\
\text { authorized weight ( MAW) } \\
\text { of the motor vehicle ( } 18 \\
\text { tonnes) and the MAW of } \\
\text { the tandem axle of the } \\
\text { semi-trailer ( } 20 \text { tonnes) are } \\
\text { respected and the driving } \\
\text { axle is fitted with twin tyres } \\
\text { and air suspension or } \\
\text { suspension recognized as } \\
\text { being equivalent }\end{array}$ \\
\hline \multicolumn{3}{|c|}{ Maximum allowed load on tridem axle of motor vehicles } \\
\hline $\begin{array}{l}\text { Sum of distances between the axles } \leq 2 \\
\mathrm{~m}\end{array}$ & $27 \mathrm{t}$ & Not defined \\
\hline
\end{tabular}

Related types of vehicles in term of allowed gross combination mass 44 tonnes:

- vehicle combination transporting containers within the combined transport,

- combination of a tractor and a cranable semi-trailer within the combined transport,

- vehicle combinations carrying a tank container or a swap body within the combined transport.

Therefore this allowed gross mass is applicable for transport of containers, swap bodies, as well as cranable semi-trailers within a combined transport regardless of the type of vehicle/vehicle combination used (however, requirements for vehicle gross mass or axle loads remain a limiting factor). Gross mass of $44 \mathrm{t}$ is not applicable to the transports within the RoLa system, where a standard gross combination mass of $40 \mathrm{t}$ is applicable $[1,6,7]$.

European Directive 2015/719/EU prescribes increased maximum allowed gross mass in intermodal transports for two-axle motor vehicle with three-axle semi-trailer carrying, in intermodal transport operations, one or more containers or swap bodies, up to a total maximum length of 45 feet gross combination mass 42 tonnes and for three-axle motor vehicle with two- or three-axle semi-trailer carrying, in intermodal transport operations, one or more containers or swap bodies, up to a total maximum length of 45 feet gross combinations mass 44 tonnes.

So the increased mass limits are not valid for transport of cranable semi-trailers because they are defined only for transport of containers or swap bodies according EU directive. Higher payload of cranable semi-trailers in intermodal transport can be used only when both a state of origin and a state of destination apply higher limits for such transports in their national legislation as Slovakia, Czech Republic or Italy does. Maximum mass of 44 tonnes may be applied only for combinations with a three-axle tractor, in other cases a maximum mass of 42 tonnes is applicable (so the increased limits in some cases do not cover even a tare mass of ILU + higher mass of three-axle tractors). Both above stated mass limits are defined only for semi-trailer combinations in EU directive. They are not applicable neither for trailer combinations (road trains), typical used e.g. for transport of two C-swap bodies (those tare mass of a about 4 tonnes lowers a payload of such road train), nor for modular road trains with both a semi-trailer and a trailer, allowing a transport 
of a container and a swap body/transport of two containers together (however, also a problem of length of such road trains has to be considered). [8,9]

Particular Member States can define the mass limits differently and do not have to prescribe higher limits than those stated in the Directive 2015/719/EU. On the contrary, they can prescribe some specific legislative rules.

In case of semi-trailer combinations, only gross combination mass (GCM) and an axle loads are considered in Slovakia. Gross mass of particular vehicles in the vehicle combination (tractor, semi-trailer) is not considered. European Directive does not use such approach, so it may be inapplicable in legislation of other countries. If maximum gross mass of a tractor and a tridem axle of semi-trailer is considered, the GCM of a combination consisting of a 2 -axle tractor and a 3 -axle semi-trailer must not exceed 42 tonnes $(18 t+24$ t) according EU directive.

In Slovakia, maximum allowed load on an extended tridem axle (sum of distances between axles maximum $2.8 \mathrm{~m}$ ) of semi-trailers/trailers is $27 \mathrm{t}$ (it means, when one of distances between the axles is over 1,4 m). This is not defined in the EU directive but it is broadly used by manufacturers of containers chassis. The combination of particular wheelbases $131+141 \mathrm{~cm}$ or $141+131 \mathrm{~cm}$ (instead of a standard combination of wheelbases $131+131 \mathrm{~cm}$ ) are usually used for such purpose. The $27 \mathrm{t}$ load on tridem axle is limited by a maximum usually used technical load of axles ( 9 t/axle) and tyres of standard semi-trailers (load index $4500 \mathrm{~kg}$ per wheel). Use of such semi-trailers allows to reach $44 \mathrm{t}$ GCM in combined transport using 2-axle tractor and a 3-axle semi-trailer equipped with the extended tridem axle $(18 t+27 t)$.

Slovak legislation specifically defines vehicle combinations with two semi-trailers or two trailers or with a semi-trailer and a trailer. Maximum allowed length/GCM of such combinations is $22 \mathrm{~m} / 40 \mathrm{t}$ (or $22.15 \mathrm{~m} / 44 \mathrm{t}$ when they are used within combined transport). However, such length is not sufficient for the European modular system (EMS). A maximum length of $25.25 \mathrm{~m}$ and a maximum mass up to $60 \mathrm{t}$ used for EMS in Nordic countries is subject to permission for abnormal transport in Slovakia. Following requirement applies for such road train with two trailers: a mass of the middle trailer has to be higher or equal to a mass of the last trailer in the combination.

A tolerance for axle loads when bulk loads are carried can be mentioned as another specific aspect of Slovak legislation. When bulk loads are carried, maximum allowed load on a single axle, tandem axle and tridem axle may be exceeded by up to $6 \%$, while a maximum allowed gross vehicle/combination mass is not exceeded (349/2009 Z. z., §4). This is applicable for a transport of bulk, unpacked solid substrates or items in vehicles, vehicle combinations, swap bodies, containers or tanks, where it is unable to secure the substrates/items to prevent movement and the cargo may move during standard transport operation, mainly due to emergency braking. This is not applicable for packed cargo, liquid and gaseous substances carried in tanks $[10,11]$.

\section{Conclusion}

Vehicles and vehicle combinations used in intermodal transport in Slovakia have to be accompanied with a declaration issued by a Loader to a road carrier. Gross mass of carried intermodal loading unit as well as a gross mass of the vehicle/vehicle combination carrying the intermodal loading unit must be presented in the declaration. The declaration shall be carried on the vehicle/vehicle combination operating on public roads (349/2009 Z. z., §5, sec. 8).

It is recommended that a declared mass should be as accurate as possible and verified by weighing (using processes according to a Methodical instruction 39/2016 on the VGM in accordance with the SOLAS Convention). 
In intermodal transports, a way of loading of intermodal loading units has a strong influence on a load distribution on particular axles. Containers should be loaded in such way, that eccentricity of a centre of gravity should not exceed $5 \%$ (not more than $60 \%$ of cargo mass in a half of a container) $[6,10,11]$.

It is very difficult to obtain accurate information about the position of a centre of gravity of ILU. Such information is usually not provided within standard business relations in comparison to the information about ILU gross mass and cargo mass.

Results of the analysis of a maximum total container gross mass in dependence on various position of a centre of gravity point at the fact that a position of containers on semitrailer container chassis is more suitable for higher allowed load of a kingpin together with the use of 3-axle tractors, because a centre of gravity may be located in the middle or slightly forwards for a maximum payload [6, 12]. Using of three-axle tractors is advantageous if higher gross mass of vehicle combinations (more than 44 tonnes) is allowed. Use of 3-axle tractors is not efficient in Slovakia because they increase vehicle combination tare mass and lower the payload with GCM of $44 \mathrm{t}$. Heavier vehicle combinations can be used as abnormal transports with the permission.

This paper is supported by the research project "From horse-drawn railway to intermodal transport" within Visegrad Fund.

\section{References}

1. J. Kubanova, C. Schmidt, Communications: Scientific letters of the University of Žilina 18, 2, 104-108 (2016)

2. O. Stopka, M. Chovancová, J. Ližbetin, V. Klapita, Naše more 63, 3, 195-199 (2016)

3. T. Skrúcaný et al., DYN-WIND’2017 (MATEC web of conferences 107, 00072, 2017)

4. J. Kubán̆ová, B. Poliaková. Transport means 2016 - 20th international scientific conference, 22-26 (Juodkrante, Lithuania, 2016)

5. J. Jagelčík, Nakladanie a upevňovanie nákladu v cestnej doprave (University of Žilina, Slovak Republic, 2015)

6. J. Jagelčák, I. Kubasáková, Naše more 61, 5-6, 106-116 (2014)

7. J. Ližbetin, O. Stopka, V. Cempírek, Naše more 63, 3, 156-160 (2016)

8. J. Zamecnik, J. Jagelcak, Communications: scientific letters of the University of Žilina 17, 4, 21-27 (2015)

9. J. Ližbetin, J. Ponický, V. Zitrický, Naše more 63, 3, 161-169 (2016)

10. J. Vrabel, J. Jagelcak, J. Zamecnik, J. Caban, Procedia Engineering 187, 89-99 (2017)

11. J. Zamecnik, J. Jagelcak, S.S. Peterssen, Communications: scientific letters of the University of Žilina 18, 2, 76-82 (2016)

12. I. Kubasakova, J. Jagelcak. Communications: scientific letters of the University of Žilina 18, 2, 109-112 (2016) 